\title{
Profitabilitas, Likuiditas, Leverage, Ukuran Perusahaan dan Prediksi Peringkat Obligasi pada Perusahaan Sektor Non Keuangan di Bursa Efek Indonesia
}

\author{
Ameilia Damayanti ${ }^{1}$, J.M.V. Mulyadi ${ }^{2}$ \\ 1,2Universitas Pancasila, Jl. Srengseng Sawah, Jagakarsa, Jakarta Selatan 12640
}

\section{N F O A R T I K E L}

\author{
JEL Classification: \\ G14 \\ G30
}

Keywords:

Profitability (ROA),

Likuidity (CR), Leverage

(DER), Pefindo, Ordina

regression

\begin{abstract}
A B S T R A C T
Bond is one of the important sources of funding for the company. The development of issuance of bonds in Indonesia is quite rapid. The study aims to determine the effect of profitability, likuidity, leverage, and firm size toward rating bond of non financial companies listed on the Indonesian Stock Exchange 2008-2012. Researchers used purposive sampling and samples used in this study were 13 companies of non finanfial companies. The analythical method used to analyze the relationship between variables is ordinal logistic regression. The results showed that profitability (ROA) no significant effect on rating bond, likuidity (CR) no significant effect on ratiing bond, leverage (DER) no significant on rating bond, and size significant effect on rating bond.
\end{abstract}

\begin{abstract}
A B S T R A K
Obligasi merupakan salah satu sumber pendanaan penting bagi perusahaan. Perkembangan penerbitan obligasi di Indonesia cukup pesat. Penelitian ini bertujuan untuk mengetahui pengaruh profitabilitas, likuiditas, leverage, dan ukuran perusahaan terhadap peringkat obligasi perusahaan non keuangan yang terdaftar di Bursa Efek Indonesia 2008-2012. Peneliti menggunakan purposive sampling dan sampel yang digunakan dalam penelitian ini adalah 13 perusahaan perusahaan non finansial. Teknik pengujian yang digunakan untuk menganalisis hipotesis hubungan antara variabel adalah regresi logistik ordinal. Hasil penelitian menunjukkan bahwa profitabilitas (ROA) tidak berpengaruh signifikan terhadap rating obligasi, likuiditas (CR) tidak berpengaruh signifikan terhadap ratiing obligasi, leverage (DER) tidak signifikan terhadap rating obligasi, dan ukuran berpengaruh signifikan terhadap rating obligasi
\end{abstract}

\section{Pendahuluan}

Menempatkan dana pada suatu aktiva yang diharapkan dapat meningkatkan nilainya di masa depan sering disebut sebagai kegiatan investasi. Secara umum investasi terbagi menjadi dua yaitu, investasi pada real assets seperti tanah, emas, benda seni. Kemudian financial assets dengan memperjualbelikan aset-aset pada pasar keuangan. Pasar keuangan

*Email Korespondensi: 'amel.damay@gmail.com,2mulyadijmv@gmail.com 
adalah pasar dari berbagai instrumen keuangan jangka panjang yang dapat diperjualbelikan, baik dalam bentuk hutang (obligasi) maupun modal sendiri (saham) yang diterbitkan pemerintah dan perusahaan swasta (Husnan, 2003).

Diantara pasar keuangan yang ada, saat ini pasar obligasi mengalami perkembangan yang cukup baik dari tahun ke tahun, walaupun perkembangannya masih lamban dibandingkan dengan saham. Perkembangan yang lamban merupakan kendala kondisi pasar obligasi yang tersedia belum dioptimalkan oleh pelaku pasar modal dan pemahaman mengenai intrumen obligasi dikalangan masyarakat umum yang masih terbatas (Raharjo, 2004).

Tabel 1

Perkembangan Obligasi

\begin{tabular}{ccccc}
\hline Year & \multicolumn{2}{c}{ Goverment bond } & \multicolumn{2}{c}{ Goverment bond } \\
& $\begin{array}{c}\text { Number of Listed } \\
\text { Series }\end{array}$ & $\begin{array}{c}\text { Outstanding Value } \\
\text { (Rp Billion) }\end{array}$ & $\begin{array}{c}\text { Number of Listed } \\
\text { Series }\end{array}$ & $\begin{array}{c}\text { Outstanding Value } \\
\text { (Rp Billion) }\end{array}$ \\
\hline 2008 & 70 & 525695 & 211 & 73010 \\
2009 & 78 & 581748 & 223 & 88452 \\
2010 & 81 & 641215 & 242 & 114817 \\
2011 & 89 & 723606 & 299 & 146969 \\
2012 & 92 & 820266 & 347 & 187461 \\
\hline
\end{tabular}

Tabel diatas merupakan data dari Bursa Efek Indonesia (BEI), obligasi pemerintah maupun obligasi perusahaan mengalami peningkatan tiap tahunnya. Meskipun demikian obligasi tetap memiliki resiko. Salah satu resiko tersebut adalah ketidakmampuan perusahaan untuk melunasi obligasi atau resiko gagal bayar (default). Agar investor memiliki gambaran tingkat risiko ketidakmampuan perusahaan dalam membayar, maka di dalam dunia surat hutang atau obligasi dikenal suatu tingkat yang menggambarkan kemampuan bayar perusahaan penerbit obligasi. Tingkat kemampuan membayar kewajiban tersebut dikenal dengan istilah peringkat obligasi (Sejati, 2010). Fenomena terkait peringkat obligasi di Indonesia terjadi pada beberapa emiten yang memiliki peringkat layak investasi (investment grade) tetapi mengalami gagal bayar (default). Tahun 2009, obligasi gagal bayar (default) terjadi pada PT Mobile -8 Telecom Tbk, telah gagal bayar 2 kali untuk kupon 15 maret 2009 dan 15 juni 2009 dengan obligasi senilai Rp 675 miliar yang jatuh tempo maret 2012. PT Davomas Abadi Tbk, obligasi senilai 235 juta dolar untuk jatuh tempo 2011 telah gagal bayar sebesar 13,09 juta untuk kupon 5 mei 2009 (Kompasiana, 9 Februari 2010). Akibatnya PT Pemeringkat Efek Indonesia menurunkan rating perusahaan yang default tersebut. Per Juni 2008 dan 2009, peringkat obligasi PT Mobile-8 Telecom Tbk pada Indonesian Bond Market Directory adalah idBBB+. Per Juni 2010, peringkatnya diturunkan menjadi idD.

PT Pefindo secara umum, dalam menilai peringkat perusahaan mencakup tiga risiko utama penilaian, yaitu risiko industri (industry risks), risiko bisnis (business risks), dan risiko finansial (financial risks), namun belum ada penjelasan lebih lanjut mengenai aspek mana yang lebih diutamakan dalam pemeringkatan dan agen pemeringkat tidak menyebutkan lebih lanjut bagaimana laporan keuangan dapat digunakan dalam menentukan peringkat obligasi. Tujuan penelitian ini adalah menguji salah satu aspek yang digunakan Pefindo dalam penilaian, yaitu aspek keuangan. Dari beberapa penelitian sebelumnya menunjukkan bahwa faktor-faktor yang mempengaruhi peringkat obligasi berbeda-beda dan beberapa hasilnya belum konklusif, sehingga peneliti tertarik untuk melakukan penelitian lebih lanjut dengan variabel yang akan digunakan dalam penelitian ini yaitu profitabilitas, likuiditas, leverage, dan menambahkan variabel ukuran perusahaan. Perbedaan dengan penelitian sebelumnya yaitu teknik analisis data dengan menggunakan regresi logistik ordinal, dari 
kriteria pengambilan sampel yang berasal dari obligasi perusahaan non keuangan yang diperingkat oleh PT Pefindo dan mengeluarkan laporan keuangan selama periode pengamatan tahun 2008-2012.

Berdasarkan latar belakang yang telah disampaikan sebelumnya, penelitian ini bermaksud menguji kemampuan rasio keuangan dalam memprediksi peringkat obligasi. Untuk itu rumusan masalah dalam penelitian ini adalah "Bagaimana pengaruh profitabilitas, likuiditas, leverage, dan ukuran perusahaan terhadap prediksi peringkat obligasi?". Tujuan penelitian ini untuk mengetahui, menguji, membuktikan dan menganalisis bahwa profitabilitas, likuiditas, leverage, dan ukuran perusahaan berpengaruh terhadap prediksi peringkat obligasi.

Penelitian ini diharapkan bisa memberikan kontribusi baik langsung maupun tidak langsung. Secara praktis diharapkan penelitian ini bisa digunakan sebagai bahan pertimbangan pengambilan keputusan untuk calon investor dan diharapkan dapat memberikan masukan bagi emiten mengenai faktor-faktor yang berpotensi mempengaruhi peringkat obligasi untuk mengingkatkan kinerja sehingga obligasi yang diterbitkan dapat terus bertahan dan bersaing di pasar modal Indonesia. Hasil penelitian ini juga diharapkan dapat memberikan wawasan pengetahuan \& penelitian di bidang keuangan dan pasar modal dan sebagai referensi bagi penelitian sejenis yang meneliti lebih mendalam di bidang investasi obligasi.

\section{Telaah Teori dan Pengembangan Hipotesis}

\subsection{Teori Keagenan dan Teori Signal}

Konflik keagenan yang berhubungan dengan penerbitan obligasi dapat terjadi antara manajemen dengan kreditor. Manajemen yang perusahaannya menerbitkan obligasi berkepentingan agar obligasi yang diterbitkan dapat terjual seluruhnya. Para kreditor berkepentingan terhadap penjaminan kondisi perusahaan penerbit obligasi dalam keadaan baik sehingga nantinya tidak mendatangkan kerugian. Untuk mengurangi konflik tersebut maka manajemen menggunakan jasa lembaga pemeringkat obligasi sehingga dalam hal ini dapat mengurangi biaya penjaminan (bonding cost).

Teori signal dalam penelitian ini menjelaskan bahwa manajemen perusahaan sebagai pihak yang memberikan signal berupa laporan keuangan perusahaan dan informasi non keuangan kepada lembaga pemeringkat. Lembaga pemeringkat obligasi ini melakukan proses pemeringkatan sehingga dapat menerbitkan peringkat obligasi bagi perusahaan penerbit obligasi ini. Peringkat obligasi ini memberikan signal tentang probabilitas kegagalan pembayaran utang sebuah perusahaan.

\subsection{Obligasi}

Bursa Efek Indonesia (2010) mengartikan obligasi sebagai surat utang jangka menengah-panjang yang dapat dipindahtangankan yang berisi janji dari pihak yang menerbitkan untuk membayar imbalan berupa bunga pada periode tertentu dan melunasi pokok utang pada waktu yang telah ditentukan kepada pihak pembeli obligasi tersebut. Jadi surat obligasi merupakan selembar kertas yang menyatakan bahwa pemilik kertas tersebut memberikan pinjaman kepada perusahaan yang menerbitkan surat obligasi.

Menurut Warsono dalam Andry (2005), emisi obligasi dapat ditinjau dari dua sisi, yaitu dari emiten maupun dari sisi investornya. Dari sisi emitennya, emisi obligasi merupakan alah satu alternatif pendanaan selain pinjaman ataupun kredit bank. Salah satu tujuan utama perusahaan emiten menerbitkan obligasi adalah untuk memperbesar nilai perusahaan, karena biaya relatif murah dibanding dengan emisi saham baru, dengan konsekuensi risiko keuangan (financial risk) yang semakin besar. Dari sisi investornya, emisi obligasi merupakan alternatif investasi yang aman. Karena obligasi memberikan pendapatan tetap berupa kupon bunga yang dibayar secara reguler dengan tingkat bunga yang kompetitif serta pokok utang yang dibayar secara tepat waktu pada saat jatuh tempo yang telah ditentuka

\subsection{Peringkat Obligasi}

Peringkat (rating) merupakan sebuah pernyataan tentang keadaan emiten dan kemungkinan apa yang bisa dan akan dilakukan sehubungan dengan utang yang dimiliki, sehingga dapat dikatakan bahwa rating mencoba mengukur risiko default, yaitu keadaan dimana emiten atau peminjam dana tidak mampu memenuhi kewajibannya. 
Semakin tinggi peringkat obligasi, semakin menunjukkan bahwa obligasi tersebut terhindar dari risiko default.

Berdasarkan Keputusan Ketua BAPEPAM dan Lembaga Keuangan Nomor: 135/BL/2006 Tentang "Pemeringkatan Atas Efek Bersifat Utang" menyatakan bahwa emiten yang akan menerbitkan obligasi wajib memperoleh pemeringkatan obligasi. Hasil pemeringkatan tersebut diterbitkan oleh lembaga pemeringkat yang telah mendapat izin usaha sebagai lembaga pemeringkat dari Badan
Pengawas Pasar Modal dan Lembaga Keuangan. Di Indonesia terdapat dua lembaga pemeringkat obligasi yaitu PEFINDO Pemeringkat Efek Indonesia) dan PT Kasnic Credit Rating. Lembaga pemeringkat memberikan peringkat obligasi setiap satu tahun sekali selama obligasi tersebut belum lunas. Pemeringkatan antara perusahaan satu dan lainnya dilakukan serentak seluruh perusahaan melainkan secara terpisah sesuai dengan perjanjian yang telah disepakati masing-masing perusahaan dengan lembaga rating.

Tabel 2

Definisi Peringkat Obligasi PT Pefindo

AAA Efek utang dengan peringkat AAA merupakan efek utang peringkat tertinggi dari Pefindo yang didukung oleh kemampuan obligor yang superior relatif dibanding entitas Indonesia lainnya untuk memenuhi 4 kewajiban finansial jangka panjang sesuai dengan yang diperjanjikan.

AA Efek utang dengan peringkat AA memiliki kualitas kredit sedikit dibawah peringkat tertinggi, didukung oleh kemampuan obligor yang sangat kuat untuk memenuhi kewajiban finansial jangka panjangnya sesuai dengan yang diperjanjikan relatif dibandingkan dengan entitas Indonesia lainnya

A Efek utang dengan peringkat A memiliki dukungan kemampuan Obligor yang kuat dibandingkan dengan entitas Indonesia lainnya untuk mememenuhi kewajiban finansial jangka panjangnya sesuai dengan yang diperjanjikan, namun cukup peka terhadap perubahan yang merugikan

BBB Efek utang dengan BBB didukung oleh kemampuan Obligor yang memadai relatif dibandingkan dengan entitas Indonesia lainnya untuk memenuhi kewajiban finansial, namun kemampuan tersebut dapat diperlemah oleh keadaan bisnis dan perekonomian yang merugikan

BB Efek utang dengan peringkat BB menunjukkan dukungan kemampuan Obligor yang agak lemah relatif dibandingkan dengan entitas lainnya untuk memenuhi kewajiban finansial jangka panjangnya sesuai dengan yang diperjanjikan, serta peka terhadap keadaan bisnis dan perekonomian yang keadaan bisnis dan perekonomian yang tidak menentu

B Efek utang dengan peringkat B menunjukkan parameter perlindungan yang sangat lemah. Walaupun obligor masih memiliki kemampuan untuk memenuhi kewajiban finansial jangka panjangnya, namun adanya perubahan keadaan bisnis dari perekonomian yang merugikan akan memperburuk kemampuan obligor untuk memenuhi kewajiban finansialnya.

CCC Efek utang dengan peringkat CCC menunjukkan efek utang yang tidak mampu lagi memenuhi kewajiban finansialnya, serta hanya tergantung kepada perbaikan keadaan eksternal.

D Efek utang dengan peringkat D menandakan efek utang yang macet. Perusahaan penerbit sudah berhenti berusaha.

Sumber: www.pefindo.com 


\subsection{Penelitian Terdahulu}

Tabel 3

Penelitian Terdahulu

\begin{tabular}{|c|c|c|c|c|}
\hline Peneliti & Judul & $\begin{array}{c}\text { Variabel } \\
\text { Independen }\end{array}$ & $\begin{array}{c}\text { Teknik } \\
\text { Analisis }\end{array}$ & Kesimpulan Penelitian \\
\hline $\begin{array}{l}\text { Raharja dan } \\
\text { Sari (2008) }\end{array}$ & $\begin{array}{l}\text { Kemampuan Rasio } \\
\text { Keuangan dalam } \\
\text { Memprediksi } \\
\text { Peringkat Obligasi }\end{array}$ & $\begin{array}{l}\text { Leverage, } \\
\text { likuiditas, } \\
\text { solvabilitas, } \\
\text { profitabilitas, } \\
\text { produktivitas }\end{array}$ & $M D A$ & $\begin{array}{l}\text { Empat variabel rasio keuangan } \\
\text { yang dapat membentuk model } \\
\text { prediksi. Liabilities/ total assets; } \\
\text { rasio Rasio leverage :long term }\end{array}$ \\
\hline Adrian (2010) & $\begin{array}{l}\text { Analisis faktor-faktor } \\
\text { yang mempengaruhi } \\
\text { peringkat obligasi } \\
\text { pada perusahaan } \\
\text { manufaktur yang } \\
\text { terdaftar di BEI }\end{array}$ & $\begin{array}{l}\text { Leverage, } \\
\text { profitabilitas, } \\
\text { likuiditas, } \\
\text { umur obligasi }\end{array}$ & $\begin{array}{l}\text { Regresi } \\
\text { Logit }\end{array}$ & $\begin{array}{l}\text { Hanya likuiditas dan umur } \\
\text { obligasi yang berpengaruh } \\
\text { terhadap peringkat obligasi }\end{array}$ \\
\hline Sejati (2010) & $\begin{array}{l}\text { Analisis Faktor } \\
\text { akuntansi dan non } \\
\text { akuntansi dalam } \\
\text { memprediksi Peringkat } \\
\text { Obligasi Perusahaan } \\
\text { Manufaktur }\end{array}$ & $\begin{array}{l}\text { Size } \\
\text { reputasi } \\
\text { auditor } \\
\text { ROA } \\
\text { CR dan growth }\end{array}$ & $\begin{array}{l}\text { Regresi } \\
\text { Logistik }\end{array}$ & $\begin{array}{l}\text { CR dan growth (faktor } \\
\text { akuntansi) berpengaruh terhadap } \\
\text { peringkat obligasi sedangkan } \\
\text { reputasi auditor (faktor non } \\
\text { akuntansi) ROA, size, tidak } \\
\text { berpengaruh terhadap peringkat } \\
\text { obligasi }\end{array}$ \\
\hline $\begin{array}{l}\text { Susilowati } \\
\& \text { Sumarto } \\
(2010)\end{array}$ & $\begin{array}{l}\text { Memprediksi Tingkat } \\
\text { Obligasi Perusahaan } \\
\text { Manufaktur yang } \\
\text { Listing di BEI }\end{array}$ & $\begin{array}{l}\text { Profitabilitas, } \\
\text { likuiditas, size, } \\
\text { maturity }\end{array}$ & $\begin{array}{l}\text { Regresi } \\
\text { logistik }\end{array}$ & $\begin{array}{l}\text { Hanya likuiditas yang signifikan } \\
\text { berpengaruh terhadap peringkat } \\
\text { obligasi }\end{array}$ \\
\hline $\begin{array}{l}\text { Estiyanti dan } \\
\text { Yasa (2012) }\end{array}$ & $\begin{array}{l}\text { Pengaruh Faktor } \\
\text { Keuangan dan Non } \\
\text { Keuangan pada } \\
\text { peringkat Obligasi di } \\
\text { BEI }\end{array}$ & $\begin{array}{l}\text { Laba ditahan } \\
\text { laba operasi } \\
\text { aliran kas } \\
\text { operasi } \\
\text { likuiditas } \\
\text { leverage, } \\
\text { umur obligasi, } \\
\text { jaminan }\end{array}$ & $\begin{array}{l}\text { Ordinary } \\
\text { Logistic } \\
\text { Regression }\end{array}$ & $\begin{array}{l}\text { Laba ditahan berpengaruh } \\
\text { positif pada peringkat obligasi } \\
\text { sedangkan laba operasi, aliran } \\
\text { kas operasi, likuiditas, total } \\
\text { asset, leverage, umur obligasi, } \\
\text { jaminan tidak berpengaruh pada } \\
\text { peringkat obligasi }\end{array}$ \\
\hline
\end{tabular}

\subsection{Kerangka Pemikiran}

\section{Hubungan antara Profitabilitas dan Peringkat Obligasi}

Profitabilitas menunjukan kemampuan perusahaan memperoleh laba baik dalam hubunganya dengan penjualan, total aktiva maupun laba bagi modal sendiri. Profitabilitas ini memberikan gambaran seberapa efektif perusahaan beroperasi sehingga memberikan keuntungan bagi perusahaan. Perusahaan yang memiliki profitabilitas tinggi akan berperingkat baik karena labayang dihasilkan dapatdigunakan untuk melunasi kewajiban. Going concern bagi sebuah perusahaan berarti perusahaan tersebut mampu mempertahankan kegiatan usahanya dalam jangka panjang dan tidak mengalami likuidasi dalam jangka pendek (Santosa dan Wedari, 2007). Menurut Purwaningsih (2008), semakin tinggi tingkat profitabilitas perusahaan maka semakin rendah risiko ketidakmampuan membayar (default), sehingga semakin baik 
peringkat yang diberikan terhadap perusahaan tersebut. Berdasarkan uraian diatas, maka hipotesis alternatif dalam penelitian ini dapat dirumuskan sebagai berikut:

H1: Profitabilitas berpengaruh terhadap prediksi peringkat obligasi

\section{Hubungan antara Likuiditas dan Peringkat Obligasi}

Likuiditas menunjukkan kemampuan perusahaan untuk membayar kewajiban finansial jangka pendek tepat pada waktunya. Tingkat likuiditas yang tinggi menandakan pelunasan kewajiban jangka pendek yang baik. Penelitian Purwaningsih (2008), menemukan hubungan yang positif antara likuiditas dengan credit rating. Semakin tinggi likuiditas perusahaan, semakin baik pula peringkat obligasi yang diberikan pada perusahaan tersebut. Burton et al (2000 dalam Devi, 2007) menyatakan bahwa tingkat likuiditas yang tinggi akan menunjukkan kuatnya kondisi keuangan perusahaan sehingga secara finansial akan mempengaruhi prediksi peringkat obligasi. Berdasarkan uraian diatas, maka hipotesis alternatif dalam penelitian ini dapat dirumuskan sebagai berikut:

$\mathrm{H} 2$ : Likuiditas berpengaruh terhadap prediksi peringkat obligasi

\section{Hubungan antara Leverage dan Peringkat Obligasi}

Rasio leverage yang merupakan pengukur tingkat proporsi penggunaan utang untuk kegiatan investasi. Jika perusahaan memiliki kesempatan utang maka dapat menambah manfaat perusahaan untuk melakukan expansi usaha. Proporsi utang yang baik adalah adanya keseimbangan antara hasil utang dengan kemampuan pelunasan kewajiban perusahaan.

Menurut Magreta dan Nurmayanti (2009) rasio ini digunakan untuk mengukur sejauh mana suatu perusahaan menggunakan utang dalam membiayai investasinya. Rendahnya nilai rasio leverage dapat diartikan bahwa hanya sebagian kecil aktiva didanai dengan utang dan semakin kecil risiko kegagalan perusahaan. Dengan demikian, semakin rendah leverage perusahaan maka akan semakin tinggi peringkat yang diberikan pada perusahaan. Berdasarkan uraian diatas, maka hipotesis alternatif dalam penelitian ini dapat dirumuskan sebagai berikut:
H3: Leverage berpengaruh terhadap prediksi peringkat obligasi

\section{Hubungan antara Ukuran Perusahaan dan Peringkat Obligasi}

Ukuran perusahaan merupakan salah satu variabel akuntansi yang mempengaruhi peringkat obligasi. Ukuran perusahaan dapat tercermin dari total aset, penjualan ataupun ekuitas yang dimiliki oleh suatu perusahaan. Dengan ukuran perusahaan, investor dapat mengetahui kemampuan perusahaan dalam membayar bunga obligasi secara periodik dan melunasi pokok pinjaman yang dapat meningkatkan peringkat obligasi perusahaan. Menurut Almilia dan Devi (2007) ukuran perusahaan juga bisa mempunyai korelasi terhadap tingkat risiko kebangkrutan atau kegagalan sehingga dapat mempengaruhi rating obligasi. Jika jumlah asset, penjualan, atau ekuitas tersebut besar, maka logaritma terhadap jumlah tersebut digunakan untuk tujuan penelitian. Berdasarkan uraian diatas, maka hipotesis alternatif dalam penelitian ini dapat dirumuskan sebagai berikut :

H4: Ukuran perusahaan berpengaruh terhadap prediksi peringkat obligasi

Dari keseluruhan teoritik tentang pengaruh profitabilitas, likuiditas, leverage, dan ukuran perusahaan terhadap prediksi peringkat obligasi yang telah dipaparkan di atas, maka dapat dibuat suatu kerangka pemikiran yang dapat digambarkan sebagai berikut:

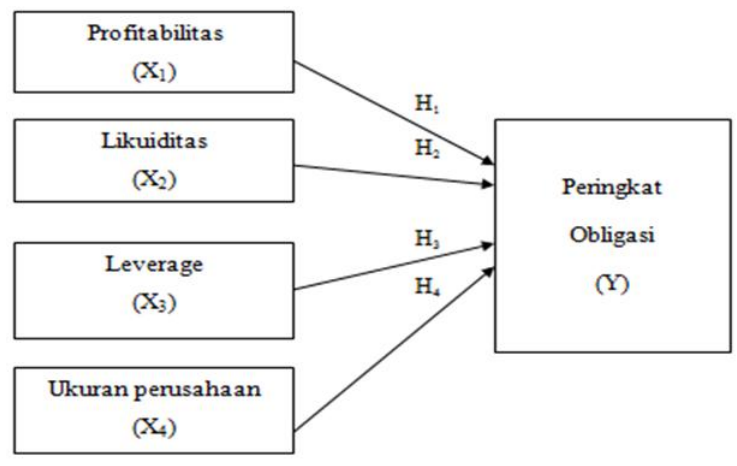

Gambar 1. Kerangka Pemikiran 


\section{Metode Penelitian}

Penelitian ini termasuk kedalam jenis penelitian kuantitatif yang mana data kuantitatif tersebut adalah data sekunder. Data sekunder yang digunakan berupa data laporan keuangan auditan perusahaan yang terdaftar di Bursa Efek Indonesia tahun 2008-2012 dalam Indonesian Capital Market Directory (ICMD), data dalam Indonesian Bond Market Directory (IBMD), serta data peringkat obligasi dari PT. Pefindo. Populasi dalam penelitian ini yaitu perusahaan sektor non keuangan yang menerbitkan obligasi dan terdaftar di Bursa Efek Indonesia (BEI) dari tahun 2008 sampai 2012. Pemilihan sampel dalam penelitian ini mengunakan metode purposive sampling. Metode pengumpulan data yang dilakukan pada penelitian ini adalah metode dokumentasi, yaitu data yang diperoleh dari berbagai dokumen atau literatur yang berkaitan dengan permasalahan yang sedang diteliti. Setelah dokumentasi, dikumpulkan, diseleksi, dan kemudian diolah.

\subsection{Definisi Operasional Variabel}

\section{Variabel Dependen}

Variabel dependen dalam penelitian ini adalah peringkat obligasi. Untuk memudahkan dalam pengolahan data mengingat adanya keterbatasan data peringkat obligasi dengan kategori non-investment grade (BB atau lebih rendah) maka peneliti melakukan modifikasi terhadap klasifikasi skala peringkat obligasi. Menurut Yuliana, dkk (2011) apabila obligasi dijamin dengan aset yang bernilai tinggi, maka rating obligasi akan semakin baik. Salah satu alasan lain yaitu dengan menjaminkan aset yang dimiliki perusahaan untuk obligasi berarti perusahaan dapat menekan risiko yang akan diterima perusahaan.

Peringkat yang digunakan dalam penelitian ini adalah peringkat berkategori investment grade. Adapun klasifikasi peringkat obligasi yang digunakan dalam penelitian adalah sebagai berikut:
Tabel 4

Klasifikasi Peringkat Obligasi

\begin{tabular}{cc}
\hline Peringkat Obligasi & Klasifikasi \\
\hline idAAA+ & 4 \\
id AAA & 4 \\
idAA+ & 3 \\
IdAA & 3 \\
idAA- & 3 \\
idA + & 2 \\
IdA & 2 \\
idA- & 2 \\
idBBB + & 1 \\
IdBBB & 1 \\
\hline
\end{tabular}

\section{Variabel Independen}

Profitabilitas (X1)

Rasio ini merupakan rasio untuk menilai kemampuan perusahaan dalam mencari keuntungan. Rasio ini juga memberikan ukuran tingkat efektivitas manajemen suatu perusahaan. Rasio ini dapat diukur dengan return on asset (ROA).

$\mathrm{ROA}=\underline{\text { Net Income }}$

Total Aset

\section{Likuiditas (X2)}

Menurut Kasmir (2009) likuiditas merupakan kemampuan perusahaan dalam melunasi kewajiban jangka pendek perusahaan. Variabel likuiditas dalam penelitian ini diproksikan dengan current ratio (CR). Menurut Almilia \& Devi (2007) perusahaan yang mampu melunasi kewajiban tepat waktu adalah perusahaan yang likuid dan mempunyai aktiva lancar lebih besar daripada utang lancar. Current ratio (CR) merupakan perbandingan antara aktiva lancar dan utang lancar.

\section{$\mathrm{CR}=\underline{\text { Current Asset }}$ Current Liabilities}

\section{Leverage (X3)}

Rasio leverage ini digunakan untuk mengukur keseimbangan proporsi antara aset yang didanai dari kreditor (utang) dan yang didanai oleh pemilik perusahaan (ekuitas). 
Tingginya nilai rasio leverage dapat diartikan bahwa sebagian besar aset didanai dengan utang dan kondisi tersebut menyebabkan perusahaan dihadapkan pada default risk atau peringkat obligasi yang rendah. Oleh karena itu, semakin tinggi rasio leverage semakin besar risiko kebangkrutan. Semakin rendah leverage perusahaan, semakin baik peringkat yang diberikan pada perusahaan. Hasil penelitian yang dilakukan oleh Sari (2007), leverage secara signifikan dapat digunakan untuk memprediksi peringkat obligasi. (Burton et al., 1998 dalam Purwaningsih, 2008). Variabel leverage di proxykan dengan Debt to Equity Ratio (DER).

DER $=\frac{\text { Total Liabilities }}{\text { Total Equity }}$

\section{Ukuran Perusahaan (Size)}

Ukuran perusahaan menunjukkan tingkat besar atau kecilnya suatu perusahaan yang dapat didasarkan pada total aktiva, penjualan, atau ekuitas. Hasil logaritma dari aktiva, penjualan, atau ekuitas tersebut mencerminkan ukuran suatu perusahaan (Miswanto \& Husnan, 1999 dalam Widya, 2005). Proksi size yang digunakan dalam penelitian ini berdasarkan pada logaritma dari total aktiva karena lebih mencerminkan kekayaan perusahaan secara menyeluruh.

\subsection{Teknik Analisis Data}

Pengujian terhadap hipotesis dalam penelitian ini dilakukan dengan analisis multivariate menggunakan regresi logistik ordinal (ordinal logistic regression). Model ini digunakan karena variabel dependen dari penelitian ini berbentuk kategorial. Teknik analisis ini tidak memerlukan lagi uji normalitas dan uji asumsi klasik pada variabel bebasnya (Ghozali, 2013).

\section{Statistik Deskriptif}

Statistik deskriptif digunakan untuk memberikan gambaran deskripsi suatu data yang dilihat dari rata-rata (mean), standar deviasi, varian, maksimum, minimum (Ghozali, 2013).

2. Pengujian Hipotesis

Tahapan dalam pengujian dengan menggunakan uji regresi logistik ordinal (ordinal logistic regression) dapat dijelaskan sebagai berikut:

a. Menilai Model Fit

Adanya pengurangan nilai antara -2LL (-2 Log Likelihood) dengan nilai -2LL pada langkah berikutnya menunjukkan bahwa model yang dihipotesiskan fit dengan data. (Ghozali,2013).

b. Goodness of fit

Selain itu diadakan pengujian Goodness of fit dengan hipotesis yang sama dimana data dikatakan fit (hipotesis nol diterima) apabila tingkat signifikansi lebih besar dari 0,05 .

c. Pseudo R Square

Dari pengukuran ini akan diketahui seberapa besar persentase variabel dependen yang mampu dijelaskan oleh variabel independen dan sisa persentase yang dijelaskan oleh variabel-variabel lain di luar model penelitian.

d. Uji Parallel Lines

Uji parallel lines digunakan untuk menguji apakah asumsi bahwa semua kategori memiliki parameter yang sama atau hubungan antara variabel independen dengan logit adalah sama untuk semua persamaan logit. Jika nilai signifikansi $\mathrm{p}>0,05$ maka model yang digunakan memiliki parameter yang sama sehingga pemilihan link function logit sudah sesuai dan uji hipotesis dapat dilakukan. Sedangkan jika nilai $\mathrm{p}$ $<0,05$ menunjukkan bahwa model yang digunakan tidak cocok (Ghozali, 2013)

e. Estimasi Parameter dan Interpretasinya Estimasi parameter dari model regresi apakah hipotesis ditolak atau diterima dapat dilihat pada tampilan output variable in equation (Ghozali, 2013). Hal yang menjadi dasar pengambilan keputusan dalam menentukan suatu variabel signifikan atau tidak signifikan yang harus dibandingkan dengan tingkat signifikan yang telah ditetapkan yaitu 0,05 (Ghozali, 2013). Apabila suatu variabel memiliki signifikansi lebih besar dari 0,05 maka variabel tersebut tidak signifikan yang memiliki arti Ho diterima dan Ha ditolak. Tetapi apabila suatu variabel memiliki signifikansi lebih kecil dari 0,05 maka variabel tersebut signifikan yang berarti Ho ditolak dan $\mathrm{Ha}$ diterima.

Adapun model hipotesisnya adalah sebagai berikut : 


$$
\begin{aligned}
& \operatorname{Logit}(p 1+p 2+\ldots . p k)=\alpha+\beta 1 X 1+\beta 2 X 2+ \\
& \beta 3 X 3+\beta 4 X 4+e
\end{aligned}
$$

Keterangan :

P : Probabilitas Peringkat obligasi

$\mathrm{P} 1=$ probabilitas peringkat obligasi cukup baik (id BBB)

$\mathrm{P} 2=$ probabilitas peringkat obligasi baik (id A)

$\mathrm{P} 3=$ probabilitas peringkat obligasi sangat baik (id AA)

$\mathrm{P} 4=$ probabilitas peringkat obligasi terbaik (id AAA)

$\boldsymbol{\alpha}$ : Konstanta

及1-5 : Koefisien regresi

X1 : Profitabilitas

X2 : Likuiditas

$\mathbf{X 3}$ : Leverage

X4 : Ukuran perusahaan

e : Standard Error

\section{Hasil Penelitian Dan Pembahasan}

\subsection{Hasil Penelitian}

Populasi dalam penelitian ini adalah perusahaan yang listing dan terdaftar di Bursa Efek Indonesia dan memiliki obligasi yang diberi peringkat oleh PT. Pefindo. Sampel pada penelitian ini dipilih dengan menggunakan metode purposive sampling yang mensyaratkan kriteria-kriteria tertentu, beberapa diantaranya adalah perusahaan sektor non keuangan, memiliki laporan keuangan lengkap tahun 2008 hingga 2012 dan obligasi yang terbit dan beredar pada tahun 2008-2012. Jumlah perusahaan sampel adalah 13 perusahaan, maka terdapat 65 sampel selama 5 tahun.

Jumlah sampel yang digunakan dalam penelitian ini adalah 65 sampel dari 13 perusahaan non keuangan dikali dengan waktu pengamatan selama 5 tahun dari 2008-2012 dengan perincian peringkat obligasi 1 sebanyak 5 sampel, peringkat obligasi 2 sebanyak 33 sampel, peringkat obligasi 3 sebanyak 26 sampel peringkat obligasi 4 sebanyak 1 sampel.

Tabel 5

Statistik Deskriptif

\begin{tabular}{lccccc}
\hline & N & Minimum & Maximum & Mean & Std. Deviation \\
\hline Profitabilitas & 65 &, 001 &, 510 &, 06782 &, 070703 \\
Likuiditas & 65 &, 117 & 3,168 & 1,53226 &, 645223 \\
Leverage & 65 &, 456 & 17,657 & 2,24431 & 2,463764 \\
Ukuran Perusahaan & 65 & 5,934 & 7,773 & 6,91465 &, 498350 \\
Valid N (listwise) & 65 & & & & \\
\hline
\end{tabular}

Dari tabel di atas dapat diketahui bahwa profitabilitas memiliki nilai minimum sebesar 0,001 (MPPA, 2008), nilai maksimum 0,510 (MPPA, 2010). Likuiditas memiliki nilai minimum sebesar 0,117 (SMRA, 2012), nilai maksimum 3,168 (PJAA, 2008). Leverage memiliki nilai minimum sebesar 0,456 (PJAA, 2011), nilai maksimum 17,657 (MAIN, 2008) dan Ukuran Perusahaan memiliki nilai minimum sebesar 5,934 (MAIN, 2008), nilai maksimum 7,773 (INDF, 2012).

Tabel 6

\begin{tabular}{|c|c|c|c|c|c|c|c|c|}
\hline \multirow{2}{*}{$\begin{array}{l} \\
\text { Threshold }\end{array}$} & \multirow[b]{2}{*}[\mathrm{PO}=1]{} & \multirow{2}{*}{$\begin{array}{r}\text { Estimate } \\
13,752\end{array}$} & \multirow{2}{*}{$\begin{array}{c}\text { ttd. Error } \\
4,712\end{array}$} & \multirow{2}{*}{$\begin{array}{c}\text { Wald } \\
8,517\end{array}$} & \multirow{2}{*}{$\frac{\text { df }}{1}$} & \multirow{2}{*}{$\begin{array}{r}\text { Sig. } \\
, 004\end{array}$} & \multicolumn{2}{|c|}{$\begin{array}{l}\text { 95\% Confindence Interval } \\
\text { Lower Bound Upper Bound }\end{array}$} \\
\hline & & & & & & & 4,516 & 22,988 \\
\hline & {$[\mathrm{PO}=2]$} & 17,033 & 4,902 & 12,075 & 1 &, 001 & 7,426 & 26,640 \\
\hline & {$[\mathrm{PO}=3]$} & 21,459 & 5,184 & 17,138 & 1 &, 000 & 11,299 & 31,619 \\
\hline
\end{tabular}

Parameter Estimates 


$\begin{array}{rlrrrrrrr}\text { Location } & \text { ROA } & 1,429 & 3,876 & , 136 & 1 & , 712 & -6,169 & 9,026 \\ & \text { CR } & , 022 & , 429 & , 003 & 1 & , 959 & -, 819 & , 863 \\ & \text { DER } & , 071 & , 121 & , 343 & 1 & , 558 & -, 166 & , 307 \\ & \text { Size } & 2,367 & , 657 & 12,994 & 1 & , 000 & 1,080 & 3,654\end{array}$

Link fuction : Logit.

Hubungan antara odd ratio dan variabel independen dapat dijelaskan sebagai berikut :

a. Kenaikan 1 unit ROA akan menaikkan odds ratio $(\exp 1,429)=4,1745$ peringkat obligasi dengan klasifikasi peringkat 4 (id $\mathrm{AAA})$ dengan catatan variabel lain ceteris paribus.

b. Kenaikan 1 unit $\mathrm{CR}$ akan menaikkan odds ratio $(\exp 0,022)=1,0222$ peringkat obligasi dengan klasifikasi peringkat 4 (id $\mathrm{AAA})$ dengan catatan variabel lain ceteris paribus.

c. Kenaikan 1 unit DER akan menaikkan odds ratio $(\exp 0,071)=1,0735$ peringkat obligasi dengan klasifikasi peringkat 4 (id $\mathrm{AAA})$ dengan catatan variabel lain ceteris paribus.

d. Kenaikan 1 unit $\log$ Size akan menaikkan odds ratio $(\exp 2,367)=10,665$ peringkat obligasi dengan klasifikasi peringkat 4 ( ${ }_{\mathrm{id}} \mathrm{AAA}$ ) dengan catatan variabel lain ceteris paribus.

Dengan exp $=$ eksponensial $(\mathrm{e})=2,71828$

\subsection{Pembahasan}

Berdasarkan hasil penelitian yang telah dilakukan dengan analisis regresi ordinal menunjukkan bahwa profitabilitas perusahaan yang diukur dengan return on asset tidak berpengaruh signifikan terhadap prediksi peringkat obligasi. Hal tersebut didasarkan pada hasil analisis regresi ordinal yang memberikan informasi bahwa variabel profitabilitas memiliki nilai signifikansi sebesar 0,712 (p>0,05) maka H1 ditolak. Alasan yang mendukung hasil riset ini adalah pengukuran profitabilitas yang berdasarkan proksi ROA kurang tepat. Ini dikarenakan ROA menunjukkan hasil (return) atas penggunaan aktiva perusahaan. Pengukuran ini akan cocok apabila diterapkan untuk menilai efektivitas manajemen dalam mengelola investasi atau mengukur tingkat kembalian investasi. Peneliti menduga pengukuran yang lebih tepat digunakan adalah profit margin. Profit margin dikatakan lebih tepat karena mencerminkan hasil kegiatan operasional perusahaan, yaitu dari hasil penjualan. Ini dikarenakan PEFINDO dalam melakukan penilaian obligasi juga berdasarkan kinerja industri yang berkaitan dengan kegiatan utama perusahaan. Bagi calon investor sebaiknya mengabaikan sinyal tentang profitabilitas perusahaan. Hasil penelitian ini sesuai dengan penelitian Susilawati (2010), Sejati (2010) dan Alwi (2012). Namun tidak sesuai dengan penelitian Manurung (2009) dimana ROA berpengaruh signifikan terhadap prediksi peringkat obligasi.

Selanjutnya, analisis regresi ordinal menunjukkan bahwa likuiditas perusahaan yang diukur dengan current assets tidak berpengaruh signifikan terhadap prediksi peringkat obligasi. Hal tersebut didasarkan pada hasil analisis regresi ordinal yang memberikan informasi bahwa variabel likuiditas memiliki nilai signifikansi sebesar $0,995(\mathrm{p}>0,05)$ maka H2 ditolak. Hal ini membuktikan bahwa meskipun current ratio yang dimiliki oleh perusahaan tinggi tidak menjamin bahwa akan memberikan peringkat obligasi yang baik terhadap perusahaan penerbit obligasi. Hal ini dikarenakan PEFINDO mungkin lebih menilai pengelolaan aset dan pasiva atas dasar laporan arus kas, yang memberikan informasi secara lebih terperinci. Enny (2011) menyatakan bahwa laporan arus kas memberikan informasi yang relevan tentang penerimaan dan pengeluaran kas. Laporan arus kas memungkinkan pengguna laporan keuangan untuk mengetahui apa yang terjadi pada sumber likuid perusahaan. Hasil penelitian ini sesuai dengan penelitian yang dilakukan oleh Estiyanti (2012), Magreta, Poppy (2009) dan Sejati (2010). Namun penelitian ini tidak mendukung hasil penelitian Susilawati (2010), dan Alwi (2012).

Leverage yang diproksikan dengan debt to equity ratio (DER) memiliki tingkat signifikansi 0,558 artinya dapat disimpulkan bahwa H3 tidak berhasil didukung, sehingga hipotesis 3 ditolak. Hasilpengujianmenunjukkan bahwa hipotesis 3 tidak berhasil didukung karena leverage tidak memiliki pengaruh yang signifikan terhadap kemungkinan obligasi memperoleh peringkat kategori yang tinggi. Hal ini dapat diartikan bahwa besar kecilnya 
leverage perusahaan tidak akan mempengaruhi peringkat obligasi. Hasil penelitian ini sesuai dengan penelitian Magreta dan Popy (2009) dan Estiyanti dan Yasa (2012) yang menemukan bahwa leverage tidak berpengaruh berpengaruh signifikan terhadap prediksi peringkat obligasi. Namun hasil penelitian ini bertentangan dengan penelitian yang dilakukan oleh Raharja dan Sari (2008) dan Purwaningsih (2008) dimana leverage berpengaruh negatif signifikan terhadap prediksi peringkat obligasi.

Ukuran perusahaan (size) memiliki tingkat signifikansi 0,000 . Nilai signifikansi ini lebih kecil dari 0,05. Artinya dapat disimpulkan bahwa H4 berhasil didukung, sehingga hipotesis 4 diterima. Hal ini berarti semakin besar ukuran perusahaan maka semakin besar kemungkinan peringkat atas obligasi yang diterbitkannya untuk mendapatkan peringkat yang tinggi. Semakin besar total aset yang dimiliki perusahaan diharapkan semakin mempunyai kemampuan dalam melunasi kewajiban di masa depan (Setyapurnama, 2004). Mengingat jumlah aset yang besar dapat dijadikan sebagai jaminan peneribitan obligasi. Informasi ini berguna untuk menurunkan tingkat ketidakpastian yang dimiliki investor. Hasil penelitian ini sesuai dengan penelitian Alwi (2012) dan Winardi (2013) yang menemukan bahwa ukuran perusahaan berpengaruh signifikan terhadap prediksi peringkat obligasi.

\section{Simpulan, Keterbatasan dan Implikasi Penelitian}

Berdasarkan hasil uji hipotesis dengan menggunakan regresi logistik ordinal dan pembahasan hasil penelitian yang telah diuraikan, penelitian ini menyimpulkan bahwa variabel profitabilitas (ROA) tidak berpengaruh terhadap prediksi peringkat obligasi. Variabel likuiditas (CR) tidak berpengaruh terhadap prediksi peringkat obligasi. Variabel leverage (DER) tidak berpengaruh terhadap prediksi peringkat obligasi dan hanya variabel ukuran perusahsaan yang berpengaruh terhadap prediksi peringkat obligasi.

Peneliti menyadari sepenuhnya bahwa penelitian yang telah dilakukan ini walaupun telah diupayakan semaksimal mungkin, akan tetapi masih mempunyai keterbatasan keterbatasan yang sulit untuk dihindari, antara lain :

1. Periode penelitian yang relatif singkat selama lima tahun dari tahun 2008 sampai dengan tahun 2012. Dengan pendeknya periode penelitian dan jumlah data yang terbatas yaitu 13 perusahaan yang menjadi sampel sehingga jumlah data yang terkumpul sebanyak 65 , maka hasilnya pun terlihat kurang optimal.

2. Penelitian ini hanya terbatas pada aspek keuangan saja yaitu profitabilitas, likuiditas, leverage, dan ukuran perusahaan, tidak menggunakan aspek lain sehingga hasil penelitian tidak dapat menggambarkan situasi secara keseluruhan

Berdasarkan keterbatasan diatas maka adapun saran yang dapat digunakan bagi pihak yang ingin melanjutkan penelitian ini adalah:

1. Penelitian selanjutnya dapat menambahkan faktor akuntansi lainnya seperti gross profit margin dan total asset turnover, serta faktor non akuntansi seperti tingkat suku bunga, volume transaksi dan yield. Kemudian disarankan juga untuk penelitian selanjutnya menggunakan variabel dengan aspek selain keuangan agar hasil penelitiannya lebih optimal.

2. Jumlah sampel dapat diambil dengan periode pengamatan yang lebih panjang dan menggunakan data peringkat obligasi dari agen pemeringkat lain selain PT PEFINDO sehingga variasi data peringkat obligasi yang diperoleh menjadi lebih banyak dan lebih optimal.

\section{Daftar Pustaka}

Adrian, Nicko. 2011. Analisis Faktor-faktor yang mempengaruhi Peringkat Obligasi Pada Perusahaan Manufaktur yang Terdaftar di Bursa Efek Indonesia. Skripsi. Semarang : Fakultas Ekonomi UNDIP

Almilia, L.S, dan Vieka Devi. 2007. Faktorfaktor yang mempengaruhi prediksi peringkat Obligasi pada perusahaan Manufaktur yang Terdaftar di Bursa Efek Jakarta. Dalam Seminar Nasional Manajemen SMART. Bandung

Alwi, Abdullah. 2012. Analisis Faktor-faktor yang Mempengaruhi Peringkat Obligasi. Universitas Semarang

Andry, Wydia. 2005. "Analisis Faktor-Faktor yang Mempengaruhi Prediksi Peringkat Obligasi".Buletin Ekonomi Moneter dan Perbankan

Enny D Maharti dan Daldjono.2011. “Analisis 
Faktor-Faktor yang Mempengaruhi Peringkat Obligasi"

Estiyanti, Ni Made dan Yasa, G.M. 2012. "Pengaruh Faktor Keuangan dan Non Keuangan pada Peringkat Obligasi di BEI'. Universtitas Udayana.

Ghozali, Imam. 2013. Analisis Multivariate Lanjutan dengan Program SPSS. Semarang: Badan Penerbit Universitas Diponegoro

Husnan, Suad. 2003. "Dasar-Dasar Teori Portofolio dan Analisis Sekuritas". Yogyakarta: Unit Penerbit dan Percetakan AMP YKPN

Kasmir. 2009. Analisis laporan Keuangan. Jakarta: Rajawali Pers.

Kompas, 2010, Tren Obligasi Gagal Bayar, Februari 2010. Diakses melalui: ompasiana. com.

Magreta dan Nurmayanti Poppy. 2009. "FaktorFaktor yang Mempengaruhi Prediksi Peringkat Obligasi Ditinjau dari Faktor Akuntansi dan Non Akuntansi." Jurnal Bisnis dan Akuntansi. Vol.11, No.3, Hal. 143-154

Manurung, A.H, Silitonga, dan Tobing. 2009. "Hubungan rasio-rasio keuangan dengan rating obligasi. Journal of Banking and Finance 3843 - 61.

Purwaningsih, Anna. 2008. "Pemilihan Rasio Keuangan untuk Memprediksi Peringkat Obligasi: Studi pada Perusahaan Manufaktur yang Terdaftar di BEJ." Kinerja, Vol 12, No.1, h. 85-99

PT PEFINDO, "Rating Definition \& Outlook", artikel diakses dari http://new.pefindo.com/ scps_rdefinitions.php?

PT PEFINDO, "Rating Methodology", artikel diakses dari http://new.pefindo.com/scrm_ lembagakeuangan_index.php?.

Raharja, dan Sari, MP. 2008. "Perbandingan Alat Analisis terhadap Peringkat Obligasi." Jurnal Maksi hal.87-104

Raharjo, Sapto. 2004. Panduan investasi obligasi. Jakarta: PT Gramedia Pustaka Utama

Santosa, A.F., \& Wedari, L.K. 2007. Analisis Faktor-Faktor Yang Mempengaruhi Kecenderungan Penerimaan Opini Audit Going Concern, Jurnal Akuntansi dan Auditing Indonesia, 11 (2): 141-158

Sari, Maylia Pramono. 2007. "Kemampuan Rasio Keuangan sebagai alat untuk Memprediksi Peringkat Obligasi." Jurnal Bisnis dan Ekonomi, Volume 14 No.2. Hal
172-182

Sejati, G.P. 2010."Analisis Faktor Akuntansi dan Non Akuntani dalam Memprediksi Peringkat Obligasi Perusahaan Manufaktur." Jurnal Ilmu Administrasi dan Organisasi, hal.70-78

Setyapurnama dan Norpratiwi. 2004. "Pengaruh Corporate Governance terhadap peringkat Obligasi dan Yield Obligasi.

Susilawati, Luky dan Sumartono.2010. “ Memprediksi Tingkat Obligasi Perusahaan Manufaktur yang Listing di BEI." Jurnal Mitra Ekonomi dan Manajemen Bisnis, Volume 1 No.2. Hal 63-175

Winardi, RD. 2013. Faktor akuntansi dan non akuntansi yang mempengaruhi Prediksi Peringkat Obligasi. Universitas Islam Syarif Hidayatullah

Yuliana Rika, Agus B, Prabowo M dan Taufik A.2011. "Analisis Faktor-Faktor Yang Mempengaruhi Prediksi Peringkat ObligasiPada Perusahaan Keuangan Yang Terdaftar Di Bursa Efek Indonesia", Simposium Nasional Akuntansi XIV. Aceh 